\title{
Glucose metabolism in 'Sphingomonas elodea': pathway engineering via construction of a glucose-6-phosphate dehydrogenase insertion mutant
}

\author{
Narendra B. Vartak, ${ }^{1} \dagger$ Chi Chung Lin, ${ }^{2}$ Joseph M. Cleary, ${ }^{2}$ \\ Matthew J. Fagan ${ }^{1}$ and Milton H. Saier, Jr' \\ Author for correspondence: Milton H. Saier, Jr. Tel: + 1619534 4084. Fax: + 16195347108. \\ e-mail: msaier@ucsd.edu
}

1 Department of Biology, University of California at San Diego, La Jolla, CA 92093-0116, USA

2 Genetics and Physiology Section, Kelco, A Unit of Monsanto Company, San Diego, CA 92123, USA

\begin{abstract}
'Sphingomonas (formerly Pseudomonas) elodea' produces the industrially important polysaccharide gellan when grown in media containing glucose. Glucose catabolic enzymes and enzymes of central carbon metabolism were assayed in crude extracts of glucose-grown cultures of this bacterium. Based on these analyses it was concluded that glucose is converted to either gluconate or glucose 6-phosphate and that both of these products are converted to 6-phosphogluconate, a precursor for the Entner-Doudoroff (ED) and pentose phosphate pathways. Phosphoglucoisomerase (Pgi) activity was detected, but the lack of phosphofructokinase activity indicated that the Embden-Meyerhof glycolytic pathway is non-functional for glucose degradation. Thus, this bacterium utilizes glucose mainly via the ED and pentose phosphate pathways. Enzyme analyses suggested the involvement of glucose-6-phosphate dehydrogenase (Zwf) in glucose utilization and $\mathrm{CO}_{2}$ production. The zwf gene was cloned from ' $S$. elodea' and partially sequenced, and a null zwf mutant was constructed. This mutant exhibited no Zwf activity in in vitro assays, grew normally on glucose minimal medium and accumulated biomass (cells plus gellan) and produced $\mathrm{CO}_{2}$ at the same rates as the parental strain. Potential explanations for this finding are provided. Clones carrying the pgi gene were isolated fortuitously.
\end{abstract}

Keywords: glucose metabolism, 'Sphingomonas elodea', glucose-6-phosphate dehydrogenase, gellan, molecular genetics

\section{INTRODUCTION}

'Sphingomonas elodea' (formerly known as Pseudomonas elodea; see Yabuuchi et al., 1990; Pollock, 1993) is a saprophytic Gram-negative bacterium originally isolated from a plant surface (genus Elodea) (Kang et al., 1982). It produces large amounts of the extracellular polysaccharide gellan, which is composed of a tetramer repeating unit consisting of D-glucosyl, D-glucuronosyl and L-rhamnosyl residues (Kang et al., 1982; Jansson et

†Present address: FMC BioProducts, 191 Thomaston Street, Rockland, ME 04841, USA.

Abbreviations: ED, Entner-Doudoroff; ICDH, isocitrate dehydrogenase; KDPG, 2-keto-3-deoxy-6-phosphogluconate; Pgi, phosphoglucoisomerase; PHB, poly- $\beta$-hydroxybutyrate. al., 1983; O’Neill et al., 1983; Sutherland, 1989; Whistler \& BeMiller, 1993). Gellan has wide-ranging commercial applications in the food industry where it can be used as a stabilizing and texturizing agent (Sanderson \& Clark, 1983 ), and in microbiology where the clarified form, GELRITE, is used for solidifying microbial media, especially those used for the isolation of thermophiles (Shungu et al., 1983; Lin \& Casida, 1984). The commercial utility of this biopolymer has been a stimulus for studying its biosynthesis.

Previous enzymic studies using gellan-producing and non-producing variants have allowed construction of a pathway for the synthesis of the nucleotide-sugar precursors of gellan (Martins \& Sa-Correia, 1991). The bacterium externally converts maltodextrin units to glucose (Lin, 1991), which provides the carbon 


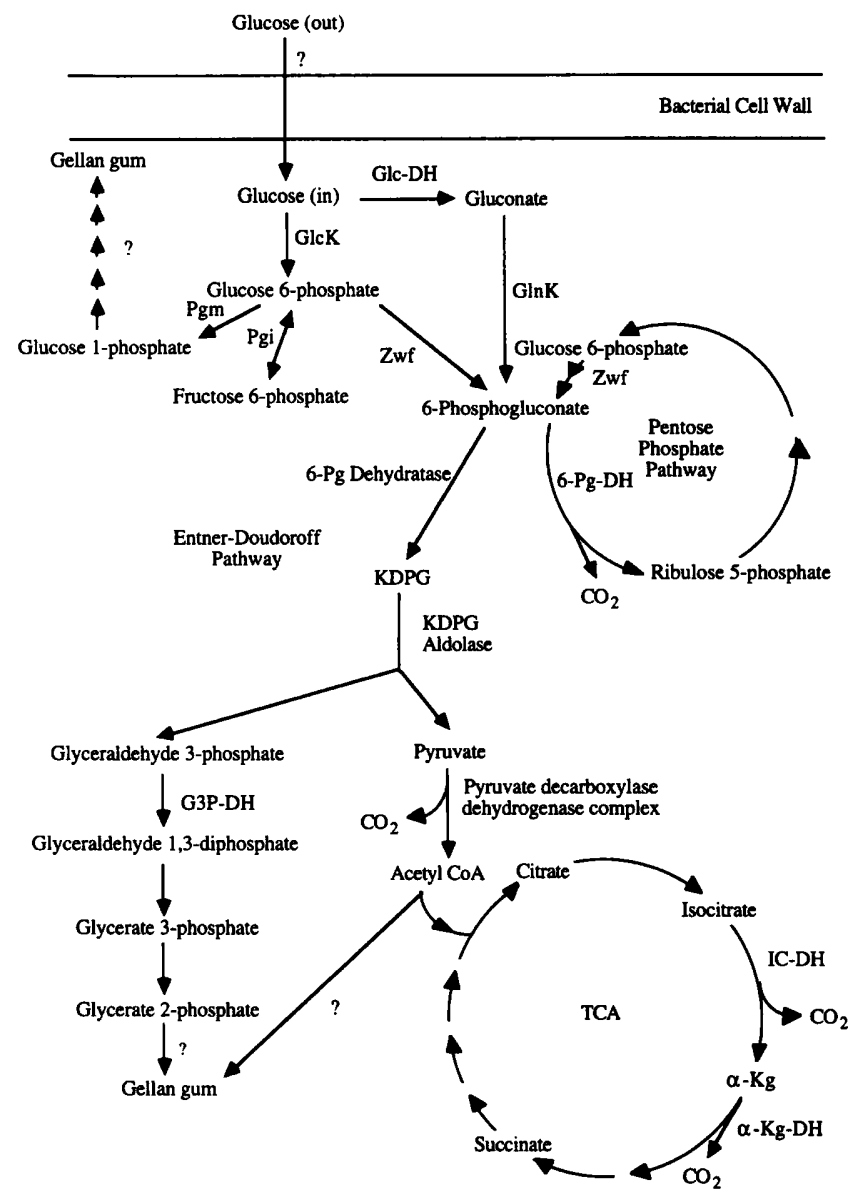

Fig. 1. Tentative schematic pathway of glucose catabolism in 'S. elodea'. $\alpha-\mathrm{Kg}, \alpha$-Ketoglutarate; $\alpha-\mathrm{KG}-\mathrm{DH}, \alpha$-ketoglutarate dehydrogenase; G3P-DH, glyceraldehyde-3-phosphate dehydrogenase; Glc-DH, glucose dehydrogenase; GlcK, glucokinase; GlnK, gluconate kinase; IC-DH, isocitrate dehydrogenase; KDPG, 2-keto-3-deoxy-6-phosphogluconate; 6-Pg-DH, 6-phosphogluconate dehydrogenase; Pgi, phosphoglucoisomerase; Pgm, phosphoglucomutase; TCA, tricarboxylic acid cycle; Zwf, zwischenferment or glucose-6phosphate dehydrogenase.

source for growth and gellan formation. Because the wild-type strain of ' $S$. elodea' also produces insoluble poly- $\beta$-hydroxybutyrate (PHB) granules which adversely affect gellan purification, a mutant strain, LPG-2, deficient in PHB production, has been constructed (Baird \& Cleary, 1974). However, this strain, like the wild-type, diverts about $50 \%$ of the carbon source to $\mathrm{CO}_{2}$ during fermentation (see Results). Thus, the available carbon is not efficiently utilized for gellan formation.

No information is currently available concerning glucose catabolism and central carbon metabolism in this bacterium. Such information would be useful in understanding the role of specific enzymes in gellan synthesis and $\mathrm{CO}_{2}$ formation. The present study was therefore initiated to reveal the biochemical pathways of glucose metabolism in the wild-type and a PHB-negative mutant of this bacterium. We demonstrate the feasibility of constructing specific mutations using a combination of molecular genetic and molecular biological methods in the absence of a defined genetic system.

Glucose catabolic enzymes and enzymes of central carbon metabolism were assayed in crude extracts of the two strains. The analyses show that both strains have high specific activities of glucose-6-phosphate dehydrogenase (Zwf) and isocitrate dehydrogenase (ICDH). Since the product of the reaction catalysed by the former enzyme, 6phosphogluconate, feeds into the pentose phosphate shunt and the tricarboxylic acid cycle, we surmised that a null mutation in zwf might reduce $\mathrm{CO}_{2}$ production without inhibiting overall carbon flow to gellan production (Fig. 1). The gene encoding this enzyme was therefore cloned and used to construct the desired null mutant.

\section{METHODS}

Chemicals, reagents and enzymes. Inorganic salts and specialized chemicals such as enzyme substrates and co-factors, antibiotics, vitamins, amino acids, isopropyl $\beta$-D-thiogalactopyranoside (IPTG) and 5-bromo-4-chloro-3-indolyl $\beta$-Dgalactopyranoside (X-Gal) were purchased from Sigma. Enzyme preparations used in coupled assays were also purchased from Sigma. Lysozyme was purchased from Boehringer Mannheim. Ticarcillin (a penicillin analogue) was purchased from Beecham Pharmaceuticals. Agar and components of LuriaBertani (LB) medium were purchased from Difco. Agarose and SeaKem Gold agarose were purchased from FMC BioProducts. Unless otherwise stated, restriction enzymes and other enzymes used in molecular cloning were purchased either from Gibco/ BRL or from New England Biolabs. The polymerase chain reaction (PCR) kit was purchased from Perkin Elmer Cetus. This kit and the various enzymes were used according to the manufacturer's instructions.

Media and growth of bacterial cells. For genetic work, Escherichia coli K12 strains were grown in either synthetic (M63) or complex (LB) media with or without agar (Miller, 1972), whereas ' $S$. elodea' cultures were grown in YT medium (Miller, 1972) lacking $\mathrm{NaCl}$ (TYE medium). E. coli and 'S. elodea' cultures used for enzymic analyses were grown overnight $(16 \mathrm{~h})$ at $37^{\circ} \mathrm{C}$ with agitation in LB and TYE medium, respectively, each containing $1 \%(\mathrm{w} / \mathrm{v})$ glucose. The medium used for bacterial fermentations was essentially the same as that described by Kang et al. (1982) and was as follows (per litre deionized water): $30 \mathrm{~g} 42 \mathrm{DE}$ corn syrup solids, $0.5 \mathrm{~g} \mathrm{~K} \mathrm{~K}_{2} \mathrm{HPO}_{4}, 0.1 \mathrm{~g}$ $\mathrm{MgSO}_{4} \cdot 7 \mathrm{H}_{2} 0,1 \cdot 1 \mathrm{~g}$ casein hydrolysate (N-Z-Amine, Quest), $5 \mathrm{mg} \mathrm{FeSO}+7 \mathrm{H}_{2} 0$, and $0 \cdot 25 \mathrm{mg} \mathrm{CoCl} \mathrm{Cl}_{2} \cdot 6 \mathrm{H}_{2} 0$.

Abbreviations for antibiotics and their respective concentrations used in media (in $\mu \mathrm{g} \mathrm{ml}^{-1}$ ) are as follows: ampicillin, Amp (100); kanamycin, Kan (30 for E. coli and 10 for ' $S$. elodea'); tetracycline, Tet (25); ticarcillin (100).

Fermentation methods. Batch fermentations were conducted in a total volume of $10 \mathrm{l}$ medium described above, in Microferm fermentors (New Brunswick Scientific) equipped with four Rushton impellers with a maximum aeration rate of $21 \mathrm{~min}^{-1}$ and an agitation rate of 1000 r.p.m. During fermentation, the medium $\mathrm{pH}$ was automatically controlled at 6.8 ; temperature was maintained at $36^{\circ} \mathrm{C}$, and foaming during the growth phase was controlled by the addition of up to $1 \mathrm{ml}$ antifoam (Hodag $\mathrm{K}-60)^{-1} \mathrm{l}^{-1} \mathrm{CO}_{2}$ concentrations in the exhaust airstream were measured using a mass spectrometer (Millipore/Extrel). The fermentation process for the manufacture of gellan (referred to 
Table 1. Bacterial strains, and plasmids used

\begin{tabular}{|c|c|c|}
\hline Strains/plasmids & Genotype/phenotype & Derivation or source \\
\hline \multicolumn{3}{|l|}{ E. coli $\mathrm{K} 12$ strain } \\
\hline TG1 & 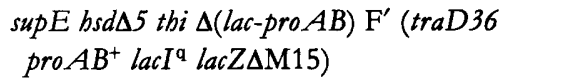 & Sambrook et al. (1989) \\
\hline DR110 & $p g i:: \operatorname{Tn} 10$ & Rowley \& Wolf (1991) \\
\hline HB351 & $\begin{array}{l}\Delta(\operatorname{argF}-l a c) U 169 z e b-1:: \operatorname{Tn} 10 \\
\Delta(e d d-z w f) 22\end{array}$ & Rowley \& Wolf (1991) \\
\hline NV998 & TG1 pgi:: Tn10 & $\begin{array}{l}\text { Transduction to } \text { Tet }^{r} \text { with } \\
\text { P1.DR110 }\end{array}$ \\
\hline NV999 & NV998 $\Delta(p g i:: \operatorname{Tn} 10)$ & $\mathrm{Tet}^{\mathrm{s}}$ derivative of NV998 \\
\hline NV1000 & $\begin{array}{l}\text { NV999 zeb-1::Tn10 } \\
(e d d-z w f) 22\end{array}$ & $\begin{array}{l}\text { Transduction to } \text { Tet }^{\mathrm{r}} \text { with } \\
\text { P1.HB351 }\end{array}$ \\
\hline NV1001 & 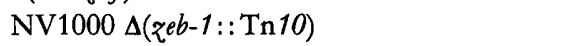 & $\mathrm{Tet}^{\mathrm{s}}$ derivative of NV1000 \\
\hline$\chi 697$ & $\begin{array}{l}\Delta(\operatorname{argF} \text { lacIPOZY } A) U 169 \text { trp } \triangle(b r n O- \\
\text { pho } A-p h o C-p h o B-p h o R) 24 \text { ara-14 } \\
\text { leuB6 aqi-6 ton } A 23 \text { lacY1 tsx-67 purE42 } \\
\text { supE44 galK2 trpE38 bis-208 argG77 } \\
\text { rpsL109 xyl-5 mtl-2 ilvE687 met A160 thi-1 }\end{array}$ & $\begin{array}{l}\text { Berg \& Curtiss (1967); } \\
\text { Vartak et al. (1991) }\end{array}$ \\
\hline \multicolumn{3}{|l|}{ E. coli plasmid } \\
\hline pBluescript II SK(+) & bla lac $Z^{\prime}$-multiple cloning site & Stratagene \\
\hline pBS-zwf & 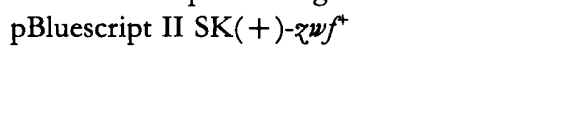 & $\begin{array}{l}\text { ₹wf PCR fragment }(0.5 \mathrm{~kb}) \\
\text { from 'S. elodea' cloned into } \\
\text { the EcoRI site }\end{array}$ \\
\hline $\mathrm{pNV1}$ & pBluescript II SK( +$)-p g i^{+}$ & $\begin{array}{l}p g i^{+} \text {clone isolated from the } \\
\text { genomic library of ' } S \text {. elodea' }\end{array}$ \\
\hline pNV8 & pBluescript II SK(+)-zwf $f^{+}$ & $\begin{array}{l}2 w f^{+} \text {clone isolated from the } \\
\text { genomic library of ' } S \text {. elodea' }\end{array}$ \\
\hline pNV10 & pNV8-qwf::kan & $\begin{array}{l}\text { kan cassette inserted into } \\
\text { unique } K p n I \text { site of 'S. elodea' } \\
\tau^{w} \text { ' gene }\end{array}$ \\
\hline \multicolumn{3}{|l|}{ 'S. elodea' strain } \\
\hline ATCC 31461 & Wild-type & ATCC \\
\hline LPG-2 & PHB-deficient mutant & $\begin{array}{l}\text { Kelco, A Unit of Monsanto } \\
\text { Company }\end{array}$ \\
\hline $\mathrm{L} 2$ and $\mathrm{L} 3$ & $\begin{array}{l}\text { Independent LPG-2 } \\
\text { ₹wf001::kan mutants }\end{array}$ & $\begin{array}{l}\text { Transformation of LPG-2 with } \\
\text { pNV10 followed by allelic } \\
\text { exchange }\end{array}$ \\
\hline
\end{tabular}

in the earlier literature as polysaccharide S-60) is covered under US patent no. 4326053 (Kang \& Veeder, 1982).

Biomass recovery, and assay methods for biomass yield and glucose equivalents. Biomass (i.e. cells plus polysaccharide) during or after fermentation was recovered from broth aliquots essentially as described by Kang et al. (1982) but with the following modifications. The broth aliquots were heated briefly to $121^{\circ} \mathrm{C}$ (15 p.s.i.; $103.5 \mathrm{kPa}$ ), and 2 vols 2 -propanol were added for precipitation. The precipitated fibres were separated by drying at $95^{\circ} \mathrm{C}$ for $18-24 \mathrm{~h}$, and the biomass yield was determined gravimetrically.

The concentration of corn syrup in the fermentation medium, measured as reducing sugar equivalents after hydrolysis with glucoamylase (Diazyme L-200, Solvay Enzymes), was determined by the dinitrosalicylic acid assay (Miller, 1959).

Bacterial strains, plasmids and genetic procedures. Table 1 lists the E. coli K12 and 'S. elodea' strains as well as the $E$. coli plasmids used. Standard genetic techniques were used for E. coli (Miller, 1972). Phage P1vir was used for generalized trans-

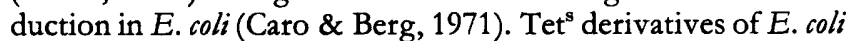
were isolated as described by Maloy \& Nunn (1981).

Extract preparation, definition of enzyme activity units, and assay procedures. Cells were centrifuged at $16000 \mathrm{~g}$ for $20 \mathrm{~min}$ ( $8000 \mathrm{~g}$ for $5 \mathrm{~min}$ for $E$. coli), washed with ice-cold $50 \mathrm{mM}$ Tris/ $\mathrm{HCl}, 10 \mathrm{mM} \mathrm{MgCl}, \mathrm{pH} 7 \cdot 8$, and resuspended in a minimal volume of the same buffer for lysis. Sonicated and Frenchpressed extracts were used for $E$. coli and ' $S$. elodea' strains, respectively. The latter bacteria were difficult to lyse (possibly due to the presence of extracellular gellan) and had to be passed through the French pressure cell 5-10 times at 2000 p.s.i. $(13.8 \mathrm{MPa})$ to obtain maximal protein yields. Extracts were centrifuged at $100000 \mathrm{~g}$ for $90 \mathrm{~min}$ to remove membrane components. Supernatants were used for assays. Protein was determined as described by Redinbaugh \& Turley (1986). Enzyme activities were uniformly expressed in $\mathrm{mU}$ (mg 
protein) $)^{-1}$. One milliunit is defined as $1 \mathrm{nmol}$ product (or cofactor) formed (or converted) $\min ^{-1}$ at $25^{\circ} \mathrm{C}$.

Phosphofructokinase activity was determined using a highspeed supernatant as described earlier by Bergmeyer (1974). The Entner-Doudoroff (ED) pathway enzymes, 6-phosphogluconate dehydratase and 2-keto-3-deoxy-6-phosphogluconate (KDPG) aldolase were assayed together as described previously by Wood (1972). Other enzymes were assayed as follows: glucokinase (Sage et al., 1990); gluconate kinase ( $\mathrm{Ng} \&$ Dawes, 1973); glucose dehydrogenase (Matsushita \& Ameyama, 1982); Zwf and phosphoglucoisomerase (Pgi) (Lessie \& Neidhardt, 1967); glyceraldehyde-3-phosphate dehydrogenase (Oshima et al., 1982); ICDH (Keys \& McAlister-Henn, 1990); phosphoglucomutase (Adhya \& Schwartz, 1971); 6-phosphogluconate dehydrogenase (Lessie \& Vander Wyk, 1972).

Electroporation. E. coli cells were electroporated by the method of Dower et al. (1988), and ' $S$. elodea' cells were electroporated by the method of Monteiro et al. (1992) except that 'S. elodea' cells were grown overnight on TYE agar and used directly for preparation of electrocompetent cells.

Routine DNA manipulations and sequencing. Chromosomal DNA was isolated from ' $S$. elodea' ATCC 31461 using the method described for $E$. coli (Schleif \& Wensink, 1981) except that cells were incubated with lysozyme at $37^{\circ} \mathrm{C}$ for $30 \mathrm{~min}$ or until visible signs of lysis were seen. Chromosomal DNA samples used for library construction were of the highest purity available. They had an $A_{\mathbf{2 6 0}} / A_{280}$ ratio of 2.0 (Sambrook et al., 1989).

Small-scale plasmid DNAs for restriction analysis were prepared as described by Sambrook et al. (1989), and large-scale plasmids for library construction were prepared using the Qiagen plasmid isolation kit.

Double-stranded DNA sequencing was performed by Sequetech using the Applied Biosystems model 373A automated sequencer coupled with fluorescent primers.

Construction of a genomic library in pBluescript II SK(+). Chromosomal DNA from ' $S$. elodea' was partially digested with Sau3AI, and fragments in the 4-8 kb size-range were isolated. Plasmid pBluescript II SK(+) DNA was digested with BamHI and dephosphorylated using calf-intestinal alkaline phosphatase (Stratagene). Vector and insert were ligated to each other in varying ratios, and the ligation reactions were individually transformed into precompetent XL1-Blue cells (Stratagene). Transformed cells were plated on $\mathrm{LB}+\mathrm{Amp}+\mathrm{IPTG}+\mathrm{X}-\mathrm{Gal}$ plates, and the plates were incubated for $16 \mathrm{~h}$ at $37^{\circ} \mathrm{C}$. About $50000 \mathrm{Amp}^{\mathrm{r}}$ colonies were isolated (blue: white colony ratio was 5:95). These were pooled, grown in LB medium containing ticarcillin for two generations to amplify the library, and a largescale plasmid preparation was made from this culture. This plasmid DNA preparation is referred to below as the library. In order to assess the cloning capacity of the primary library, it was transformed into $\chi 697$, a multiauxotrophic strain of E. coli K12, and the following frequencies of marker complementation were obtained (Vartak \& Saier, 1992). The number of prototrophic colonies $/ \mathrm{Amp}^{\mathrm{r}}$ transformant for each marker were: 0 (leuB, $1.5 \mathrm{~min}$ ), $2.5 \times 10^{-5}$ (purE, $\left.12 \mathrm{~min}\right), 1.25 \times 10^{-5}$ (trpE, $28 \mathrm{~min}$ ), $5 \times 10^{-5}$ (bis, $\left.44 \mathrm{~min}\right), 1 \times 10^{-7}$ (argG, $\left.69 \mathrm{~min}\right), 5 \times 10^{-4}$ (ilvE, $85 \mathrm{~min})$ and $0(\operatorname{met} \mathrm{B}, 91 \mathrm{~min})$.

Synthetic oligodeoxynucleotides. Unless otherwise stated, oligodeoxynucleotides were purchased from Oligos Etc. They were resuspended in distilled water, and the solution concentrations were determined spectrophotometrically (Sambrook $e t$ al., 1989).
Amplification of zwf sequences using PCR. The sequence of the deoxyinosine-containing degenerate oligonucleotide primer ZWF-1 was 5'-CAC GAATTC GAT(C) CAT(C) TAT(C) T(C)TI GGI AAA(G) GA-3', and that of ZWF-2 was $5^{\prime}$-CAC GAAT'TC A(G)AA IGG IAC ICC III CCA ICT(G)-3'. These two primers were designed on the basis of the sequence homology found between the different Zwf proteins (see Fig. 3) and have a built-in EcoRI site for cloning the resulting PCR fragment. A $50 \mu \mathrm{l}$ reaction mixture contained the following: $500 \mathrm{ng}$ chromosomal DNA (' $S$. elodea' ATCC 31461, Pseudomonas aeruginosa PAO1, or E. coli TG1), $0.3 \mathrm{nmol}$ each primer, $10 \mathrm{nmol}$ each dNTP, $1.25 \mathrm{U}$ AmpliTaq DNA polymerase in $10 \mathrm{mM}$ Tris $/ \mathrm{HCl}$ (pH 8.3), $50 \mathrm{mM} \mathrm{KCl}, 1.5 \mathrm{mM}$ $\mathrm{MgCl}_{2}$ and $0.001 \%$ gelatin. The reaction was overlaid with $50 \mu \mathrm{l}$ mineral oil. The thermocycling parameters used were: initial denaturation at $94^{\circ} \mathrm{C}$ for $4 \mathrm{~min}$, then 5 cycles of $94^{\circ} \mathrm{C}$ for $1 \mathrm{~min}$, $37^{\circ} \mathrm{C}$ for $1 \mathrm{~min}$, and $72^{\circ} \mathrm{C}$ for $1 \mathrm{~min}$, with a slow rise (over a 2 min period) from $37^{\circ} \mathrm{C}$ to $72{ }^{\circ} \mathrm{C}$, followed by 25 cycles at $94{ }^{\circ} \mathrm{C}$ for $1 \mathrm{~min}, 45^{\circ} \mathrm{C}$ for $1 \mathrm{~min}$, and $72{ }^{\circ} \mathrm{C}$ for $1 \mathrm{~min}$. The reaction mixture $(5 \mu \mathrm{l})$ was electrophoresed on a $1 \%(\mathrm{w} / \mathrm{v})$ agarose gel. The wild-type strain of $P$. aeruginosa, PAO1, was a gift from Dr P. Phibbs, East Carolina University, Greenville, NC, USA.

Digoxigenin-11-dUTP-labelling and synthesis of the zwf probes by PCR. Non-radioactive probes were employed in Southern and colony hybridizations. The Genius System from Boehringer Mannheim Biochemicals was used for labelling and detecting nucleic acids using digoxigenin-11-dUTP (dig-dUTP) as the non-radioactive label. The manufacturer's protocol was used for labeling nucleic acid probes by PCR. About one-third (by mole) of dig-dUTP was used to replace dTTP in the reactions. The PCR products labelled with this ligand migrated more slowly than the non-labelled ones because of the presence of this heavy molecule in the product.

The probe used in the colony hybridization experiments was generated using ' $S$. elodea' chromosomal DNA as a template and ZWF-1 and ZWF-2 as primers in a $50 \mu \mathrm{l}$ PCR reaction identical to the one described previously but carrying approximately onethird (by mole) of the dig-dUTP label.

Colony hybridization procedures. Bacterial colonies grown overnight on LB + Amp agar plates were blotted onto Hybond$\mathrm{N}$ nylon membranes (Amersham International) and treated for lysis and fixation according to the manufacturer's protocol. Colorimetric detection of dig-dUTP-labeled probe-template hybrids was carried out using components of the Genius System kit according to the accompanying protocol.

Computer analysis of DNA sequences. Translations of DNA sequences obtained from GenBank and EMBL databases were analysed using both commercially available Macintosh software (DNA Strider), and VMS software (GCG package, University of Wisconsin, Madison, WI, USA). The FASTA and MaIlfasta programs (Pearson \& Lipman, 1988) were used for homology searching. The Newat program (Feng \& Doolittle, 1990) was used for multiple alignment of protein sequences and construction of the phylogenetic tree. The prokaryotic/eukaryotic divergence time was calculated as described by Doolittle et al. (1989).

\section{RESULTS}

\section{Glucose metabolism in 'S. elodea'}

We initially set out to determine the mode of glucose utilization with the intent of improving the efficiency of gellan synthesis. Earlier work had shown that in the wild- 
Table 2. Specific activities of glucose catabolic enzymes and enzymes of central carbon metabolism in the wildtype and the PHB-deficient mutant (LPG-2) of 'S. elodea'

A mean of two or more independent determinations is tabulated. ND, Not detected.

\begin{tabular}{|lcc|}
\hline Enzyme & \multicolumn{2}{c|}{$\begin{array}{c}\text { Specific activity } \\
\text { [mU }\end{array}$} \\
& (mg protein) ${ }^{-1}$ ] \\
\cline { 2 - 3 } & Wild-type & LPG-2 \\
\hline Glucose dehydrogenase & 5 & $5 \cdot 5$ \\
Glucokinase & $4 \cdot 6$ & $17 \cdot 6$ \\
Gluconate kinase & $4 \cdot 9$ & $0 \cdot 5$ \\
Zwf & 21 & $15 \cdot 5$ \\
6-Phosphogluconate dehydrogenase & $2 \cdot 7$ & $4 \cdot 2$ \\
ED enzymes (6-phosphogluconate & $0 \cdot 02$ & $0 \cdot 03$ \\
dehydratase and KDPG aldolase) & \multicolumn{2}{c}{} \\
Glyceraldehyde-3-phosphate & $5 \cdot 8$ & $7 \cdot 8$ \\
dehydrogenase & \multicolumn{2}{c}{} \\
ICDH & 47 & 87 \\
Phosphoglucomutase & $2 \cdot 9$ & $3 \cdot 3$ \\
Phosphofructokinase & ND & ND \\
\hline
\end{tabular}

type strain up to $50 \%$ of available carbon is converted to $\mathrm{CO}_{2}$ during gellan fermentation. These measurements were performed in a series of fermentation experiments using a mass spectrometer as described in the Methods section, and averaged a $\mathrm{CO}_{2}$ conversion rate of $45 \%$ (with a maximum of $50 \%$ ) (G. P. Shimizu, unpublished results). In order to reduce the $\mathrm{CO}_{2}$ production by genetic alteration, we wanted to understand which enzymes were important to its production. Since information concerning glucose catabolism in the genus Sphingomonas is not available, we assayed for the presence of several glucosespecific catabolic enzymes as well as enzymes of central carbon metabolism. Glucose-grown late-exponential stage cultures of 'S. elodea' were used. It should be noted that gellan synthesis is maximal during this stage of growth (Martins \& Sa-Correia, 1991).

In bacteria, glucose can enter several routes of catabolism:

(1) Glucose (Glc) out $\rightarrow$ Gluconate $_{\text {out }} \rightarrow$ Gluconate $_{\text {in }} \rightarrow$ Gluconate 6-phosphate

(2) $\mathrm{Glc}_{\text {out }} \rightarrow \mathrm{Glc}_{\text {in }} \rightarrow$ Gluconate $\rightarrow$ Gluconate 6phosphate

(3) Glc $_{\text {out }} \rightarrow$ Glc 6-phosphate in $_{\rightarrow} \rightarrow$ Gluconate 6-phosphate $\rightarrow$ ED pathway

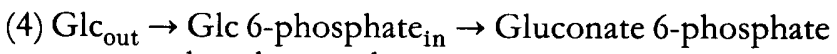
$\rightarrow$ pentose phosphate pathway

(5) Glc $_{\text {out }} \rightarrow$ Glc 6-phosphate in $_{\rightarrow}$ Glycolysis

Preliminary enzymic data suggested that routes (2) and (3) might be the pathways for the initiation of glucose catabolism in 'S. elodea'. Exogenous gluconate utilization was not observed in cultures of the wild-type strain ATCC 31461 as monitored by HPLC (C. C. Lin, unpublished results). We used the PHB-deficient derivative, LPG-2, as well as the wild-type strain primarily because of the inability of the former strain to divert carbon to PHB formation. In both of these strains we found that glucose catabolism was probably initiated by the actions of glucokinase and glucose dehydrogenase which yield glucose 6-phosphate and gluconate, respectively (Table 2). Glucose 6-phosphate is converted to fructose 6phosphate by the action of phosphoglucose isomerase and to glucose 1-phosphate by the action of phosphoglucomutase. The latter activity has been reported previously by Martins \& Sa-Correia (1991). No further phosphorylation of fructose 6-phosphate seems to occur as evidenced by the lack of phosphofructokinase activity (Table 2). Glyceraldehyde-3-phosphate dehydrogenase activity was also found (Table 2).

Gluconate can be further converted to 6-phosphogluconate by the action of gluconate kinase, whose activity was detected. 6-Phosphogluconate can also be formed via the action of Zwf, an enzyme with high specific activity. Because 6-phosphogluconate serves as a precursor for the $\mathrm{ED}$ and the pentose phosphate pathways, we assayed for the presence of enzymes of these pathways.

\section{Detection of ED and pentose phosphate pathway enzymes}

Both ED enzymes, 6-phosphogluconate dehydratase and KDPG aldolase, were detected (Table 2). The specific activity of these enzymes was significantly lower than those of the other enzymes assayed. The activity of 6phosphogluconate dehydrogenase, a pentose phosphate pathway enzyme, was also detected (Table 2). ICDH, a tricarboxylic acid cycle enzyme which generates $\mathrm{CO}_{2}$, exhibited high specific activity.

\section{Cloning of the zwf gene}

The high specific activity of $\mathrm{Zwf}$ in cultures grown in glucose suggested that this enzyme might be a fruitful target of mutation. A genomic library of ' $S$. elodea' was constructed in pBluescript $\mathrm{SK}(+)$. It was screened for the presence of a $q w f^{+}$clone in a $q w f p g i$ double mutant of $E$. coli, NV1001. Because this strain lacks both Zwf and Pgi, enzymes vital to glucose degradation, it does not grow on glucose minimal medium unless transformed with a $2 w f^{+}$ or a $p g i^{+}$plasmid. NV1001 cells were transformed with the library, and several hundred $\mathrm{Glc}^{+}$colonies were obtained. Colony size varied from large to small, the small ones appearing after a $2-3 \mathrm{~d}$ incubation period at $30^{\circ} \mathrm{C}$. Enzyme analyses of crude extracts prepared from 100 colonies (both large and small) showed that none exhibited Zwf activity and all had Pgi activity. A restriction map of one representative $\mathrm{pgi}^{+}$plasmid is shown in Fig. 2(a). Complementation thus failed to yield a $2 w f^{+}$clone. 
(a)

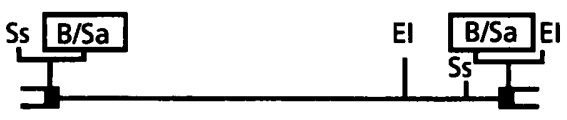

pNV1

(b)

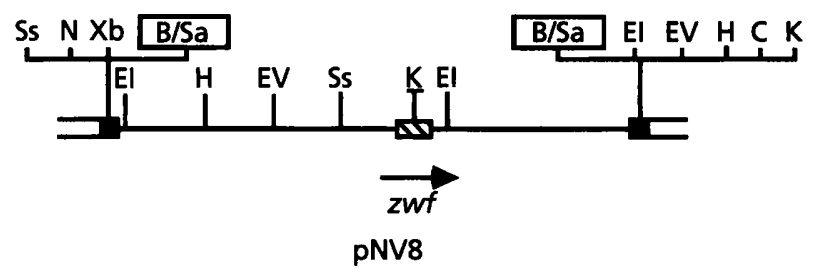

Fig. 2. Restriction maps of pgit plasmid pNV1 (a) and $z w f^{+}$ plasmid pNV8 (b). The exact location of the pgi gene on pNV1 is unknown. The Kpnl site within zwf is underlined and the direction of transcription for this gene is shown with an arrow. Restriction sites within the zwft insert were not found for Clal, Scal and Xbal. B, BamHI; C, Clal; El, EcoRI; EV, EcoRV; H, HindIII; K, Kpnl; N, Notl; Sa, Sau3Al; Ss, Sstl; Xb, Xbal. Solid line, insert DNA; ${ }^{2}$, vector DNA with its multiple cloning site;

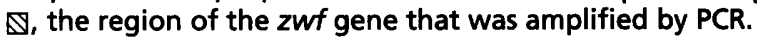

In order to isolate a $2 w f^{+}$clone by colony hybridization, a homologous probe was generated by PCR using degenerate primers designed on the basis of the sequence homologies of different Zwf proteins (see Fig. 3). Chromosomal DNA of 'S. elodea' was amplified using the Zwf-specific degenerate primers as described in Methods. The amplification reaction expectedly produced a product approximately $0.5 \mathrm{~kb}$ in length from ' $S$. elodea' as well as from a control reaction using $E$. coli DNA as template (Fig. 4, lanes 1 and 3). In the case of the control reaction using $P$. aeruginosa DNA as template (Fig. 4, lane 2), a $0.5 \mathrm{~kb}$ reaction product was generated; however, in addition, a $1.0 \mathrm{~kb}$ product was also obtained. This additional product was not investigated and could have resulted from binding of either of the primers to a competing template. The amplification product of ' $S$. elodea' was cloned into the EcoRI site of pBluescript II $\mathrm{SK}(+)$ and sequenced at each of its extremities using $\mathrm{T} 3$ 17-mer and T7 17-mer primers (Stratagene). Although the sequence had several gaps, translation revealed that one reading frame encoded a product that had several amino acyl residues (identified by asterisks in Fig. 3) that were aligned to, and conserved in, all Zwf proteins (see 'Sel', Fig. 3). The GC content of the 103 bases sequenced was found to be $60 \%$ (not shown), in agreement with that found earlier for ' $S$. elodea' by the $T_{m}$ method (Kaneko \& Kang, 1979). Thus, the $0.5 \mathrm{~kb}$ PCR product was identified as an authentic $2 w f$ sequence, probably originating from the 'S. elodea' zwf gene. The 'S. elodea' product was cloned into the EcoRI site of pBluescript, and the resulting construct was designated $\mathrm{pBS}-2 w f$. Digestion of pBS- $2 w f$ with several commonly used restriction enzymes revealed a unique $K p n \mathrm{I}$ site almost in the middle of the cloned product (also see Fig. 2).

Using a digoxigenin-labelled $0.5 \mathrm{~kb}$ zwf product of ' $S$. elodea' as a probe, we screened recombinant colonies from the plasmid library. XL-1 Blue cells were transformed with the library, and $A m p^{r}$ colonies were isolated on several LB + Amp plates. These were examined using this probe. Eight positive clones were identified from a screening of $10000 \mathrm{Amp}^{\mathrm{r}}$ colonies. In order to confirm that each of these clones carried a $2 w f^{+}$plasmid, we tried to reamplify the $0.5 \mathrm{~kb}$ zwf gene product using their respective plasmid DNAs as templates together with ZWF-1 and ZWF-2 as primers. Using the same thermocycling parameters employed in amplifying the chromosomal copy of $z w f$, we could detect this typical $0.5 \mathrm{~kb} z w f$ product from each of the eight plasmids (results not shown). In a control experiment, pNV1 $\left(p g i^{+}\right)$failed to give this product, thus excluding the possibility that the E. coli zwf gene was amplified from traces of contaminating genomic DNA that may have been present in the plasmid preparations.

The restriction map of one representative clone, designated pNV8, is presented in Fig. 2(b). It had a single KpnI site within the insert, presumably the same as that found in $\mathrm{pBS}-q w f$, and a neighbouring EcoRI site. There was enough DNA flanking this site to encode the entire zwf coding region. We determined the DNA sequences of the regions flanking the highly conserved regions 1 and 2 in pNV8 in order to confirm that it was indeed a genuine $2 w f^{+}$clone. Translation of the sequences revealed that one reading frame encoded an amino acid sequence that showed perfect alignment of conserved residues (Fig. 3, bottom row, ' $\mathrm{pNV8}$ '). The partial sequence of this protein was not the same as any of the other known Zwf proteins; therefore it identified a new Zwf sequence. Stringent Southern analysis showed that this clone did not hybridize to chromosomal DNAs of either E. coli or $P$. aeruginosa (data not shown). However, it did hybridize to chromosomal DNA of ' $S$. elodea', confirming that pNV8 contained the $z w f$ sequence originating from 'S. elodea'. In addition, a single EcoRI site was found in the partial DNA sequence of pNV8 located within the region defined by the residues 'HVDN...RLREV' as seen in Fig. 3. These data along with the knowledge of the location of the KpnI site in pNV8 allowed us to determine the direction of transcription of $z^{w f}$ in pNV8, which is as shown in Fig. 2(b).

Independent transformation of NV1001 using each of the eight $z w f^{+}$plasmid DNAs showed no complementation of its growth defect on glucose. However, similar experiments using plasmid pPZ301 DNA (Temple et al., 1990) and plasmid pTC117 (a Zymomonas mobilis zwf ${ }^{+}$clone from Dr T. Conway, University of Nebraska, Lincoln, NE, USA) DNA carrying the $P$. aeruginosa and $Z$. mobilis $z w f$ genes, respectively, resulted in complementation of the glucose defect of this strain, in each case. This result, although surprising, was consistent with our inability to clone this gene based on complementation. No Zwf activity was detectable in crude extracts of these $z w f^{+}$clones suggesting a lack of promoter activity. 


\section{Disruption of the zwf gene of 'S. elodea' by insertion of a kan cassette}

A $1.2 \mathrm{~kb}$ Tn5-derived Kan resistance cassette (kan) was inserted into the unique $K p n I$ site of the $q w f$ gene. First, a filled-in XbaI-ClaI $q w f$ fragment from pNV8 was subcloned into a filled-in SstI-KpnI digested pBluescript plasmid, and the resulting plasmid was called pNV9. Then, a $1.2 \mathrm{~kb}$ filled-in EcoRI-Bst $\mathrm{BI}$ fragment carrying the kan gene of Tn 5 isolated from plasmid pIF198 (Beck et al., 1982; Berg et al., 1992) was inserted into the KpnI site of the ' $S$. elodea' $z w f$ gene in pNV9 by blunt-ended ligation. In order to confirm that the $q w f$ gene had been mutated by insertion of this cassette, four resulting $₹ w f:$ : kan plasmids (pNV10, numbers 1-4) were used as templates in a PCR reaction using ZWF-1 and ZWF-2 as primers. Disruption of the zwf gene would be expected to result in failure to obtain the $0.5 \mathrm{~kb} q w f$ product typical of this reaction. pNV8 and pNV9 were used as positive controls. Fig. 5 shows the results of this experiment. As expected, controls pNV8 and pNV9 (lanes 5 and 6 , respectively) gave the typical $0.5 \mathrm{~kb}$ PCR product; however, pNV10 (numbers $1-4$, lanes $1-4$ ) gave a $1.6 \mathrm{~kb}$ product. This result showed that insertion of this cassette into the $K p n I$ site of pNV9 indeed resulted in the disruption of the $q 2 \mathrm{f}$ gene sequence on this plasmid, thereby expanding this region by $1.2 \mathrm{~kb}$. A faint $0.5 \mathrm{~kb}$ PCR product seen in these lanes was most likely the product of amplification of the $E$. coli chromosomal $z w f$ gene present as a contaminant in the plasmid mini-preps. Undigested plasmid DNAs showed this contaminating chromosomal DNA (data not shown).

\section{Construction of a chromosomal zwf ::kan insertion mutant of 'S. elodea'}

A zwf : : kan insertion mutant of ' $S$. elodea' was constructed by allelic exchange and selection following electroporation of pNV10 into strain LPG-2. This approach, termed 'reversed genetics' (Weissmann et al., 1979), has been useful for isolating mutants in bacterial genera for which conventional methods of mutagenesis are unavailable. Because this plasmid has an E. coli origin of replication, it cannot be maintained in ' $S$. elodea', and its introduction into ' $S$. elodea' cells by transformation leads to its loss by segregation at each cell division. We took advantage of this fact in the construction of a $z w f:$ : kan insertion mutant of ' $S$. elodea'.

LPG-2 cells were independently electroporated with intact and ScaI-linearized pNV10 DNA. $\mathrm{Kan}^{\mathbf{r}}$ transformants were selected on TYE + Kan agar at $30^{\circ} \mathrm{C}$ and $37^{\circ} \mathrm{C}$. In both cases, colonies appearing on this medium were mainly of two types: ones which grew in $2 \mathrm{~d}$ and others which took an additional $3 \mathrm{~d}$ to grow at room temperature. Both types of colonies were replica plated on TYE + Amp agar, in addition to TYE + Kan agar, to see if the plasmids had integrated into the chromosome by homologous crossover events. In most cases the large colonies were plasmid cointegrants, able to grow on Amp, whereas the small colonies were non-cointegrants, unable to grow on Amp. The latter $\left(\operatorname{Kan}^{\mathrm{r}} \mathrm{Amp}{ }^{\mathrm{s}}\right)$ colonies were assumed to be putative qwf::kan insertion mutants.
Upon re-streaking, the small and large colonies gave rise to colonies which had similar sizes revealing that the differences in initial colony sizes were due to differences in growth lag, rather than growth rate. Two putative mutants, L2 and L3, showed no detectable Zwf activity in vitro. In comparison, wild-type and LPG-2 cells showed specific activities of 34 and 46, respectively. As positive controls, crude extracts of all four strains showed normal Pgi activities (data not shown).

\section{Growth and fermentation characteristics of the zwf001:: kan insertion mutant L3}

To see if the $2 w f$ insertion mutation in 'S. elodea' slowed growth on glucose-containing media, overnight TYEgrown cultures of LPG-2 and the mutant L3 were streaked on TYE agar containing $0.5 \%$ glucose as well as on $0.5 \%$ glucose minimal agar. Plates were incubated for 24 and $48 \mathrm{~h}$ at $37^{\circ} \mathrm{C}$. The mutants L2 and L3 formed colonies that had a similar size $(1-3 \mathrm{~mm})$ to those of wild-type cells. This result was consistent with the observation that the 'glucose equivalents' utilized by the parent and the zwf mutant during gellan production were similar (see below). Thus, as in E. coli, the zwf mutation did not appreciably depress glucose utilization.

In order to determine if a block in $₹ w f$ affected gellan yield, the insertion mutant L3 was compared with its parent LPG-2 for gellan production in two independent batch fermentations. The time courses for mean total biomass formation (cells plus gellan) and mean sugar consumption were determined as described in Methods and plotted (Fig. 6). Both strains performed similarly with respect to these parameters. From an initial sugar concentration of about $30 \mathrm{~g}^{-1}$, LPG-2 and L3 formed a mean of $12 \cdot 7$ and $12.3 \mathrm{~g} \mathrm{l}^{-1}$ of total biomass, respectively. The rate of glucose utilization as assessed by monitoring glucose equivalents remaining in the fermentation medium was similar for the two strains (Fig. 6). Also, the total $\mathrm{CO}_{2}$ evolution at the end of the fermentation period was similar, i.e. $23 \cdot 2 \mathrm{~g} \mathrm{l}^{-1}$ for LPG-2, and $22 \cdot 8 \mathrm{~g} \mathrm{l}^{-1}$ for L3 (data not shown). Therefore, fermentation characteristics of the two strains did not prove to be significantly different.

\section{DISCUSSION}

Glucose metabolism was studied in two gellan-producing strains of ' $S$. elodea', the wild-type and a PHB-deficient mutant. Our enzyme analyses suggested that in both strains, glucose utilization was initiated by the actions of glucokinase and glucose dehydrogenase as shown in Fig. 1. No exogenous gluconate utilization was observed. This is in contrast to the situation in pseudomonads which can convert glucose externally to gluconate and then to 2ketogluconate before transporting the latter two compounds for cytoplasmic catabolism (Lessie \& Phibbs, 1984). ' $S$. elodea' possessed the ED and the pentose phosphate pathway enzymes but lacked the glycolytic enzyme phosphofructokinase. This observation suggested that the classical Embden-Meyerhof-glycolytic 
Hea (1)

Rno (1)

Dme (1)

Sce (1)

Eco (1)

Zmo (1)

Ime (1)

Hea (21)

Rno (57)

Dme (61)

Sce (37)

Eco (35)

Zmo (36)

Imo (32)

Hsa (82)

Rno (117)

Dme (121)

Sce $(100)$

Eco (98)

Zmo (100)

Ime (92)

Sel (?)

pNV8

Hsa (143)

Rno (178)

Dme (182)

Sce (164)

Eco (154)

Zmo (156)

Ime (156)

Sel (?)

pNV8

Hsa (208)

Rno (243)

Dme (247)

Sce (229)

Eco (219)

Zmo (221)

Ime (221)

Sel (?)

pNV8

Hsa (273)

Rno (308)

Dine (312)

Sce (294)

Eco (284)

Zmo (286)

Ime (286)

Sel (?)

pNV8

Hsa (335)

Rno (370)

Dime (374)

Sce (356)

Eco $(346)$

Zmo (348)

Ime (348)

Sel (?)

pNV8
MAEOVALSRTOVCGIIREEL YOGDAFHOADTHIF IMGASGDIAKOKIYYT IWWLF

MATEDHTALDL IKSLKSP TMVCEGTHFDGK IPHTFVIFGASGDLAKXKIYP TLWWLY MSEGPVKFEKN TVISVFGASGDIAKCOTIFPALFGLF MAVTQTAQACDLV IFGAKGDLARRKLIPSLYQIE MTNTVSTMI IFGSTGDLSQRMILPSLYGLDADGLI MVSE IKTLVTFEGGTGDLAKRKIYP SVFNLY

(56)

(60)

(36)

(34)

(35)

(31)

(81)

(116)

(120)

(99)

(97)

(99)

(91) ADGLLADDLRIVCTSRSEYDT DGERDEAEKAIDRFVASDRLNDDAKAKKFLNKLFYATVDITDRT KKGYLOKEFAIVGTAROLAND DEFKOLVRDSTKDF TDDOAOAEAF IEHF SYRAHDVTDAA

(142)

(177)

(181)

(163)

(153)

(155)

(155)

(?)

GENVRISIEKPIGRDL

QSSDRLSNHISSLFREDOIYRIDHYLGKEMVONLMVLRFANRIFGP IWNRDNIACVILTEKEPFC QSSNQLSNHISSLFREDQIYR IDHYLGKEMVQNLMVLRFANR IFGP IWNRDN IACVILTFKRPFG ASSAGLSDHLAGLFQEDQL YRIDHYLGKEMVQKIMT IRFGNKILSSTWNREN IASVL ITFKEPFG ASARELOKNL GALFKREEL YRIDHYLGKELVKNLLVLRFGNOF LNASWNRDNIOSVOISEKRRFG ATSQEINDQVGE YFEECQVYRIDHYLGKE TVLNLIAIRFANSLFVNNWDNRTIDHVEITVAEEVG ASSDHI NAVLKVESELQVYRIDHYLGKETVQNLLTIRFGNALFEPLWNSKGIDHVQISVAETVG DTAAELQNDLENAFDDNQLFRIDHYLGKEMVQMIAATRFGNP IFDAAWNKDYIKNVQVTLSEVLG DHYLGKETVQN?LA?RF? NSLFEP ?WN?? ? I

ASNRE INDIVAEAFPEERTFRIDHYLGKETVONILSLR

TEGRGGYFDEFGIIRDVMQNHLLOMLCLVAMEKP ASTDSDDVRDEKVKVLKCISEVETDNVVLGO TQGRGGYF DEFGIIRDVMQNHLLQILSLVAMEKPVSCHPDDIRDEKVKVLKS IEALTLDDMVLGQ TEGRGGYF D IG I IRDVMQNHLLQIMTLLTMIRPVSFDPES IRDEKVKVLKAVAP IDTDDVLLGQ IEGRWGYFDKAGOMRDMIONHLLOILCMIAMSPPSDLSADSIRDEKVKV PEVSSPHRPLORTRK LEGRIGYFDGSGSLRDMVQSHILQLVALVAMEPP AHMEANAARDEKVKVFRALRP INNDTVETHT VEERAGYYDTAGALLDMIONHTMQIVGWLANEKPESFTDKD IRAAKNAAFNAIKIVDEAEVNKYF

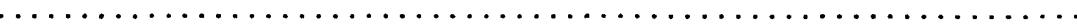

YVGN PDG EGEATKGYLDDPTVPRGSTTATFAAVVLYVENERWDGVPFILRCGKALNERKAEV YVGN PSG EGEATNGYLDDPTVPHGSTTATFAAAVL YVENERWDGVPF ILRCGKALNERKAEV YLGN PQGTNDDARTGYVEDPTVSNDSNTP TYAARSLKINNERWQGVPE ILRCGKALNERKAEV $Y$ GK $S$ EDGSKPAYVDDDTVDKDSKCVTF AAMTFNIENERWEGVP IMMRAGKALNESKVEI NRTRAIYCVPQGXKVP GYLEEEGANKSSNTE TFVAIRVDIDNWRWAGVPF YLRTGKRLPTKCSEV VTGQYGAGVSGGKEVAGYIDELG QP SDTETFVAIKAHVDNWRWQGVPFYIRTGKRIPARRSE I VRAQ YGAGDSADFKPYLEELDVPADSKNNTF IAGELQFDLPRWEGVPFYVRSGKRLAAKQTRV

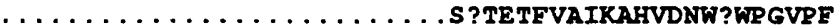
HVDNWRWQGVPFYLRTGKRLAERRSEI

*

RLQFHDVAGDIFH QQCKRNELVIRVQPNEAVYTKMMTKKPGM RLQERDVAGDIFH QQCKRNELVIRVQP NEAVYTKMMTKKPGM RIQYQDVLGDIFE GNTKRNELVIRVQP GRALYFKMMTKSPGI FFNPEESELDLTYGNRY FFNPEESELDLTYGNRY TFDIEETELDLTYEHRY RLOYKAVASGVF KDIPNNELVIRVOPDAAVYLKFNAKTPGL SNATOVTDLNLTYASRY VVYFKTPELNLFKESWQDLPQNKLTIRLQPDEGVDIQVLNKVPGLDHK HNLQITKLDLSYSETF VVQFKPVPHS IF SSSGGILQPNKLRIVLQPDET IQISMMVEPGLDRQGAKMREVWLDLSLTDVF DIVFKAGTFN FGSE QEAQEAVLSIIIDPKGAIELKLNAKSVA DAFNTRTIDIGWTVSDE

VIQFKPVPHS IF AERGGMLQPNALVIRLQPEEYVQLLVMAKQPGFDREGYRLREV

Fig. 3. For legend see facing page. 
Hsa (394)

Rno (429)

Dme (433)

Sce $(412)$

Bco $(410)$

Zmo (413)

Lime (408)

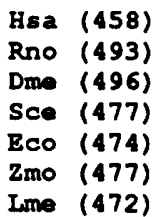

$\star \star$

$\star \quad$ *

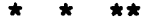

KNVXLPDAYERLILDVECGSQMAIFVRSDELREAWRIFTPLLHOIEI EXPKP IPYIYGSRGPTEA KWVKLPDAYERLILDVECGSOMHFVRSDELREAWRIFTPLLHKIDR EKPOP IPYVYGSRGP TEA KDSYLPDAYERLILDVFCGSQMAFVRSAA AQAWRIFTPILEQIEK EHIRP ITYQYGSRGPKRA QDFWIPEAYEVLIRDALLGDHSNEVRDDELDISWGIFTPLIKHIERPDGPTPEIYPYGSRGPKGL NQTHLADAYERLLIETMRGIQALFVRRDEVEEAKKWVDS ITEAKAY DNDAPKPYQAGTWGPVAS KDRLRRIAYERIMLDLIEGDATLEVRRDEVEAQWVWIDGIREGTKA OSMITKTYYSGTYGPSTA DKONTPEP YERMIHDTMNGDGSNFADWNGVS IAKKFVDAISAVYTA DKAPIETYKSGSMGPEAS

(457)

(492)

(495)

(476)

(473)

(476)

(471)

(480)

(515)

(522)

(506)

(488)

$(489)$

(486)

Fig. 3. Multiple alignment of the known Zwf protein sequences. Standard one letter amino acid designations are used. The seven proteins shown are homologous based on comparison scores which varied for the binary comparisons between 22 and 88 SD. The amino acid sequences were translations of the GenBank DNA sequences and were aligned using the Newat program (Feng \& Doolittle, 1990). Abbreviations used and GenBank or EMBL accession numbers are as follows: Hsa, Homo sapiens (M12996); Rno, Rattus norvegicus (X07467); Dme, Drosophila melanogaster (M26674); Sce, Saccharomyces cerevisiae (M34709); Eco, E. coli (M55055); Zmo, Zymomonas mobilis (M60615); Lme, Leuconostoc mesenteroides (M64446); Sel, partial 'S. elodea' sequence determined from pBS-zWf; pNV8, partial zwf sequence flanking the two conserved regions 1 and 2 (see further) and originating from plasmid pNV8. Asterisks above the sequences indicate residues conserved in all Zwf proteins. The highly conserved regions 1 and 2 which were used in designing the deoxyinosine-containing degenerate oligonucleotide primers occur in line four (DHYLGKE) and in line six (RWXGVPX), respectively. Question marks in the 'S. elodea' zwf gene sequence denote positions where residue assignment was ambiguous. These ambiguities did not affect the sequence of bases located downstream and revealed conserved residues in the 'S. elodea' zwf gene.

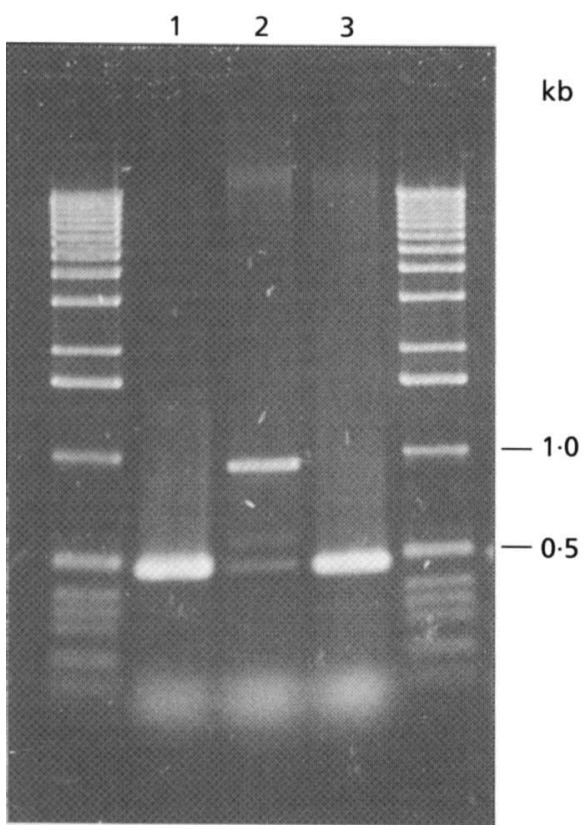

Fig. 4. Results of the amplification of $z w f$ sequences using chromosomal DNAs as template and ZWF- 1 and ZWF-2 as deoxyinosine-containing degenerate oligonucleotide primers. Ten percent of the reaction mixture was electrophoresed from each PCR reaction on a $1 \%$ agarose gel as described in Methods. Lanes: $1, E$. coli TG1 DNA; 2, P. aeruginosa PAO1 DNA; 3, 'S. elodea' ATCC 31461 DNA. The BRL 1 kb ladder provided molecular size markers shown on either side of the sample reactions.

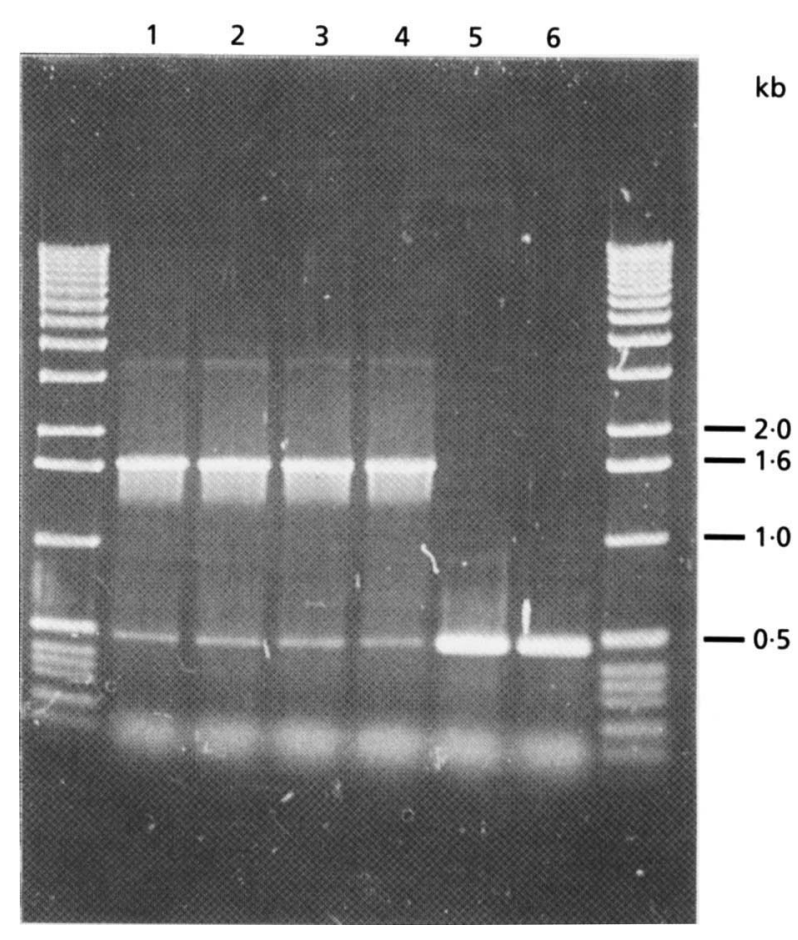

Fig. 5. Results of the amplification reactions using plasmids pNV10 (four sub-clones) as templates (lanes 1-4, respectively) and ZWF-1 and ZWF-2 as the degenerate primers. Plasmids pNV8 and pNV9 $\left(z w f^{+}\right)$were used as positive controls (lanes 5 and 6). The $1 \mathrm{~kb}$ ladder from BRL was run in lanes to the extreme left and right. 


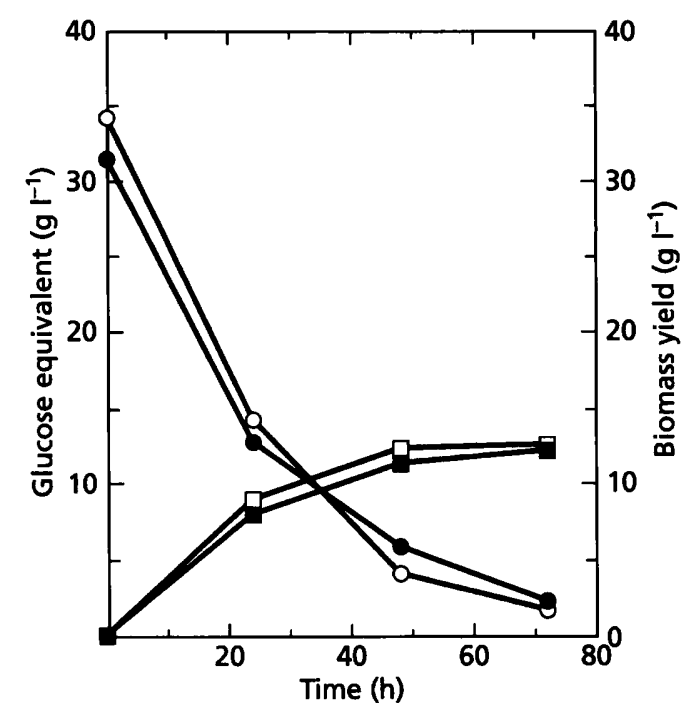

Fig. 6. Rates of sugar consumption and total biomass formation by LPG-2 and the $2 w f 001:: k a n$ insertion mutant L3 during gellan fermentation. $O$, LPG-2 glucose equivalents; $\square$, LPG-2 yield; O. L3 glucose equivalents; $\square$, L3 yield. Values were determined as described in Methods, and were measured at 24, 48 and $72 h$.

pathway does not exist in this bacterium. Glucose is probably converted to 6-phosphogluconate via either of two routes before the latter compound enters the ED and pentose phosphate pathways (Fig. 1).

As a result of the in vitro enzyme analyses reported, the zwf gene was chosen for mutational analysis. Thus, inactivation of Zwf might be expected to channel additional carbon towards gellan synthesis. We constructed mutants $\mathrm{L} 2$ and L3, and these strains were shown to lack Zwf activity in vitro. Surprisingly, L3 was not affected in glucose utilization, gellan production or total $\mathrm{CO}_{2}$ evolution compared to its wild-type parent (Fig. 6 and Results). This result suggests that at least in the $z w f$ mutant, glucose is utilized via a route involving glucose dehydrogenase and gluconate kinase. Either this is the principal route for carbon catabolism in 'S. elodea', or the loss of $\mathrm{Zwf}$ resulted in a compensatory induction of these enzymes.

The lack of complementation observed when the putative $2 w f^{+}$plasmids were transferred to $E$. coli deserves comment. As shown in Fig. 2(b), sufficient DNA exists in pNV8 (and other clones not described herein) to encode the entire $z w f$ gene and its promoter. Lack of complementation therefore suggests that such a promoter was not active in the E. coli strain. Possibly the zwf gene is a distal cistron in an operon whose promoter was not cloned in our $2 w f^{+}$plasmids. Both in E. coli (Rowley \& Wolf, 1991) and in P. aeruginosa (Temple et al., 1990) zwf is transcribed independently, whereas in Z. mobilis (Barnell et al., 1990) it appears to be the second cistron of an operon consisting of four genes. The 'S. elodea' pgi gene and the $P$. aeruginosa and $Z$. mobilis $2 w f$ genes were

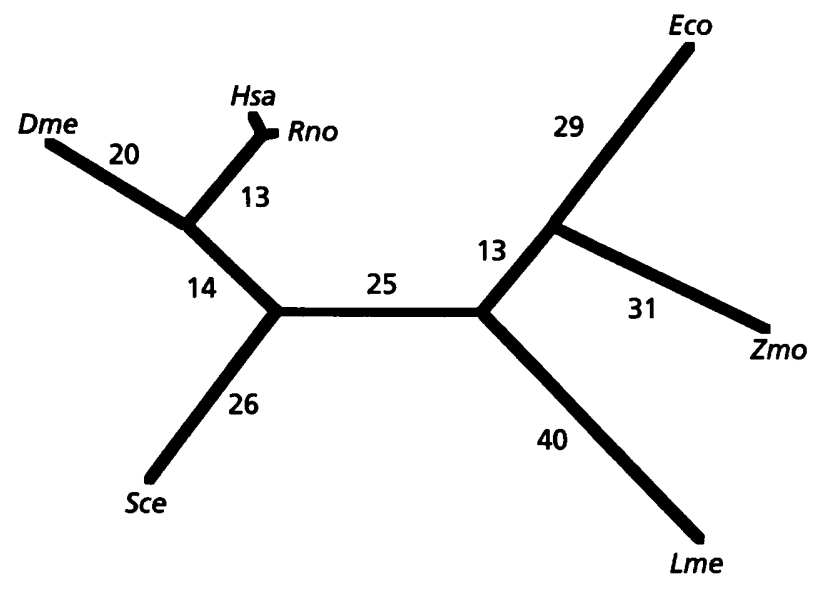

Fig. 7. Phylogenetic tree of fully sequenced Zwf proteins. The TREE program of Feng \& Doolittle (1990) was used. The prokaryotic/eukaryotic divergence time, calculated from the sequences, was 1.6 billion years ago (Doolittle et al., 1989).

functionally expressed in NV1001, ruling out the possibility of a strain-dependent lack of gene expression.

As part of the Zwf sequence comparisons conducted in conjunction with these studies (see multiple alignment, Fig. 3) we constructed a phylogenetic tree of the Zwf family proteins as shown in Fig. 7. The four eukaryotic proteins in this family cluster together as do the three prokaryotic sequences. Moreover, the relative phylogenetic distances of these proteins correlate with the phylogenetic distances established for the organisms within experimental error. Thus, for example, the two mammalian proteins are tightly clustered, the Drosophila protein is more distant, the yeast protein is still more distant from the aforementioned eukaryotic proteins, and the bacterial proteins comprise distant branches on the tree (Fig. 7). The prokaryotic/eukaryotic divergence time determined as described by Doolittle et al. (1989) using the seven Zwf sequences was 1.6 billion years ago, in reasonable agreement with the value of 1.8 billion years, established on the basis of comparisons with many other protein sequences (Doolittle et al., 1989). The fossil record suggests a slightly greater divergence time. The results clearly suggest that the seven sequences studied represent orthologous proteins which evolved as a result of species divergence from a single ancestral gene encoding a protein functionally the same as the present day $\mathrm{Zwf}$.

The molecular genetic approach utilized here in conjunction with biochemical and physiological studies is potentially useful for answering important questions pertaining to glucose catabolism and its relation to the efficiency of gellan synthesis. Such studies will impact upon any strain development scheme undertaken. These will be further aided by the recent discovery of sphinganase, an enzyme which hydrolyses gellan, facilitating easy manipulation of ' $S$. elodea' cells (Mikolajczak et al., 1994). 


\section{ACKNOWLEDGEMENTS}

We thank Drs B. Bachmann, T. Conway and P. Phibbs, Jr, for gifts of strains and plasmids used in this study, and Drs J. K. Baird, N. E. Harding and G. P. Shimizu of Kelco, A Unit of Monsanto Company, for discussions and suggestions on the manuscript. We are indebted to Kelco, A Unit of Monsanto Company for the postdoctoral support of N.B.V. This work was in part supported by USPHS grants 5 RO1AI 21702 and 2 RO1AI 14176 from the National Institute of Allergy and Infectious Diseases.

\section{REFERENCES}

Adhya, S. \& Schwartz, M. (1971). Phosphoglucomutase mutants of Escberichia coli K-12. J Bacteriol 108, 621-626.

Baird, J. K. \& Cleary, J. M. (1994). PHB-free gellan gum broth. US Patent 5300429.

Barnell, W. O., Yi, K. C. \& Conway, T. (1990). Sequence and genetic organization of a Zymomonas mobilis gene cluster that encodes several enzymes of glucose metabolism. J Bacteriol 172, 7227-7240.

Beck, E., Ludwig, G., Auerswald, E. A., Reiss, B. \& Schaller, H. (1982). Nucleotide sequence and exact localization of the neomycin phosphotransferase gene from transposon Tn5. Gene 19, 327-336.

Berg, C. M. \& Curtiss, R., III (1967). Transposition derivatives of an Hfr strain of Escherichia coli K-12. Genetics 56, 503-525.

Berg, C. M., Vartak, N. B., Wang, G., Xu, X., Liu, L., MacNeil, D. J., Gewain, K. M., Wiater, L. A. \& Berg, D. E. (1992). The $m \gamma \delta-1$ element, a small $\gamma \delta(\operatorname{Tn} 1000)$ derivative useful for plasmid mutagenesis, allele replacement and DNA sequencing. Gene 113, 9-16.

Bergmeyer, H. U. (1974). Methods of Enzymatic Analysis. Weinheim: Verlag Chemie.

Caro, L. G. \& Berg, C. M. (1971). P1 transduction. Methods Enqymol 12, 444-458.

Doolittle, R. F., Anderson, K. L. \& Feng, D.-F. (1989). Estimating the prokaryote-eukaryote divergence time from protein sequences. In The Hierarchy of Life, pp. 73-85. Edited by B. Fernholm, K. Bremer \& H. Jornwall. Amsterdam: Elsevier Science.

Dower, W. J., Miller, J. F. \& Ragsdale, C. W. (1988). High efficiency transformation of E. coli by high voltage electroporation. Nucleic Acids Res 16, 6127-6145.

Feng, D. \& Doolittle, R. F. (1990). Progressive alignment and phylogenetic tree construction of protein sequences. Methods Enzymol 183, 375-387.

Jansson, P., Lindberg, B. \& Sandford, P. A. (1983). Structural studies of gellan gum, an extracellular polysaccharide elaborated by Pseudomonas elodea. Carbobydr Res 124, 135-139.

Kaneko, T. \& Kang, K. S. (1979). Agar-like polysaccharide produced by a Pseudomonas species: taxonomic studies. In Abstracts of the 79th Annual Meeting of the American Society for Microbiology, abstract I-37, p. 101. Washington, DC: American Society for Microbiology.

Kang, K. S. \& Veeder, G. T. (1982). Polysaccharide S-60 and bacterial fermentation process for its preparation. US Patent 4326053.

Kang, K. S., Veeder, G. T., Mirrasoul, P. J., Kaneko, T. \& Cottrell, I. W. (1982). Agar-like polysaccharide produced by a Pseudomonas species: production and basic properties. Appl Environ Microbiol 43, 1086-1091.

Keys, D. A. \& McAlister-Henn, L. (1990). Subunit structure, expression and function of $\mathrm{NAD}(\mathrm{H})$-specific isocitrate dehydrogenase in Saccharomyces cerevisiae. J Bacteriol 172, 4280-4287.
Lessie, T. \& Neidhardt, F. C. (1967). Adenosine triphosphate-linked control of Pseudomonas aeruginosa glucose-6-phosphate dehydrogenase. J Bacteriol 93, 1337-1345.

Lessie, T. G. \& Phibbs, P. V., Jr (1984). Alternate pathways of carbohydrate utilization in pseudomonads. Annu Rev Microbiol 38, 359-387.

Lessie, T. G. \& Vander Wyk, J. C. (1972). Multiple forms of Pseudomonas multivorans glucose-6-phosphate and 6-phosphogluconate dehydrogenases: differences in size, pyridine nucleotide specificity, and susceptibility to inhibition by adenosine $5^{\prime}$ triphosphate. J Bacteriol 110, 1107-1117.

Lin, C. C. (1991). Maltodextrin metabolism in Pseudomonas elodea during gellan fermentation. In Abstracts of the Annual Meeting of the Society for Industrial Microbiology, abstract P-9, p. 86. Anandale, VA: Society for Industrial Microbiology.

Lin, C. C. \& Casida, L. E. (1984). GELRITE as a gelling agent in media for the growth of thermophilic microorganisms. Appl Environ Microbiol 47, 427-429.

Maloy, S. R. \& Nunn, W. D. (1981). Selection for loss of tetracycline resistance by Escherichia coli. J Bacteriol 145, 1110-1112.

Martins, L. O. \& Sa-Correia, I. (1991). Gellan gum biosynthetic enzymes in producing and non-producing variants of Pseudomonas elodea. Biotechnol Appl Biochem 14, 357-364.

Matsushita, K. \& Ameyama, M. (1982). D-Glucose dehydrogenase from Pseudomonas fuorescens, membrane-bound. Methods Enzymol 89, 149-154.

Mikolajczak, M. J., Thorne, L., Pollock, T. J. \& Armentrout, R. W. (1994). Sphinganase, a new endoglycanase that cleaves specific members of the gellan family of polysaccharides. Appl Environ Microbiol 60, 402-407.

Miller, G. L. (1959). Use of dinitrosalicylic acid reagent for determination of reducing sugar. Anal Chem 31, 426-428.

Miller, J. H. (1972). Experiments in Molecular Genetics. Cold Spring Harbor, NY: Cold Spring Harbor Laboratory.

Monteiro, G. A., Fialho, A. M., Ripley, S. J. \& Sa-Correia, I. (1992). Electrotransformation of gellan-gum producing and non-producing Pseudomonas elodea strains. $J$ Appl Bacteriol 72, 423-428.

Ng, F. M. \& Dawes, E. A. (1973). Chemostat studies on the regulation of glucose metabolism in Pseudomonas aeruginosa by citrate. Biocbem J 132, 129-140.

O'Neill, M. A., Selvendran, R. R. \& Morris, V. J. (1983). Structure of the acidic extracellular gelling polysaccharide produced by $P_{s e u d o-}$ monas elodea. Carbobydr Res 124, 123-133.

Oshima, T., Fujita, S. C. \& Imahori, K. (1982). Glyceraldehyde 3phosphate dehydrogenase from Thermus thermophilus. Methods Enzymol 89, 335-340.

Pearson, W. R. \& Lipman, D. J. (1988). Improved tools for biological sequence comparison. Proc Natl Acad Sci USA 85, 2444-2448.

Pollock, T. J. (1993). Gellan-related polysaccharides and the genus Sphingomonas. J Gen Microbiol 139, 1939-1945.

Redinbaugh, M. G. \& Turley, R. B. (1986). Adaptation of the bicinchoninic acid protein assay for use with microtiter plates and sucrose gradient fractions. Anal Biochem 153, 267-271.

Rowley, D. L. \& Wolf, R. E. (1991). Molecular characterization of the Escherichia coli K-12 zwf gene encoding glucose 6-phosphate dehydrogenase. $J$ Bacteriol 173, 968-977.

Sage, A., Linker, A., Evans, L. R. \& Lessie, T. G. (1990). Hexose phosphate metabolism and exopolysaccharide formation in Pseudomonas cepacia. Curr Microbiol 20, 191-198. 
Sambrook, J., Fritsch, E. F. \& Maniatis, T. (1989). Molecular Cloning: a Laboratory Manual. Cold Spring Harbor, NY: Cold Spring Harbor Laboratory.

Sanderson, G. R. \& Clark, R. C. (1983). Laboratory-produced microbial polysaccharide has many potential food applications as a gelling, stabilizing, and texturizing agent. Food Technol 37, 63-70.

Schleif, R. F. \& Wensink, P. C. (1981). Practical Methods in Molecular Biology. Berlin: Springer-Verlag.

Shungu, D., Valiant, M., Tutlane, V., Weinberg, E., Weissberger, B., Koupal, L., Gadebusch, H. \& Stapley, E. (1983). GELRITE as an agar substitute in bacteriological media. Appl Environ Microbiol 46, $840-845$.

Sutherland, I. W. (1989). Bacterial exopolysaccharides - their nature and production. In Antibiotics and Chemotberapy, pp. 50-55. Edited by H. Schonfeld. Basel: Karger.

Temple, L., Cuskey, S. M., Perkins, R. E., Bass, R. C., Morales, N. M., Christie, G. E., Olsen, R. H. \& Phibbs, P. V., Jr (1990). Analysis of cloned structural and regulatory genes for carbohydrate utilization in Pseudomonas aeruginosa PAO. J Bacteriol 172, 6396-6402.

Vartak, N. B. \& Saier, M. H., Jr (1992). A genomic library of the gellan gum producing organism Pseudomonas elodea. In Abstracts of the 5th American Society for Microbiology Conference on Genetics and
Molecular Biology of Industrial Microorganisms, abstract B-27, p. 18. Washington, DC: American Society for Microbiology.

Vartak, N. B., Liu, L.، Wang, B. \& Berg, C. M. (1991). A functional leu $A B C D$ operon is required for leucine synthesis by the tyrosinerepressible transaminase in Escherichia coli $\mathrm{K}-12$. J Bacteriol 173, 3864-3871.

Weissmann, C., Nagata, S., Tanaguchi, T., Weber, H. \& Meyer, F. (1979). The use of site-directed mutagenesis in reversed genetics. In Genetic Engineering, Principles and Methods, pp. 133-150. Edited by J. K. Setlow \& A. Hollaender. New York: Plenum Press.

Whistler, R. L. \& BeMiller, J. N. (1993). Industrial Gums: Polysaccharides and their Derivatives. San Diego: Academic Press.

Wood, W. A. (1972). Assay of enzymes representative of metabolic pathways. Methods Microbiol 6A, 411-424.

Yabuuchi, E., Yano, I., Oyaizu, H., Hashimoto, Y., Ezaki, T. \& Yamamoto, H. (1990). Proposals of Sphingomonas paucimobilis gen. nov. and comb. nov., Sphingomonas parapaucimobilis sp. nov., Sphingomonas yanoikuyae sp. nov., Sphingomonas adhaesiva sp. nov., Sphingomonas capsulata comb. nov., and two genospecies of the genus Sphingomonas. Microbiol Immunol 34, 99-119.

Received 8 February 1995; revised 5 April 1995; accepted 27 April 1995. 